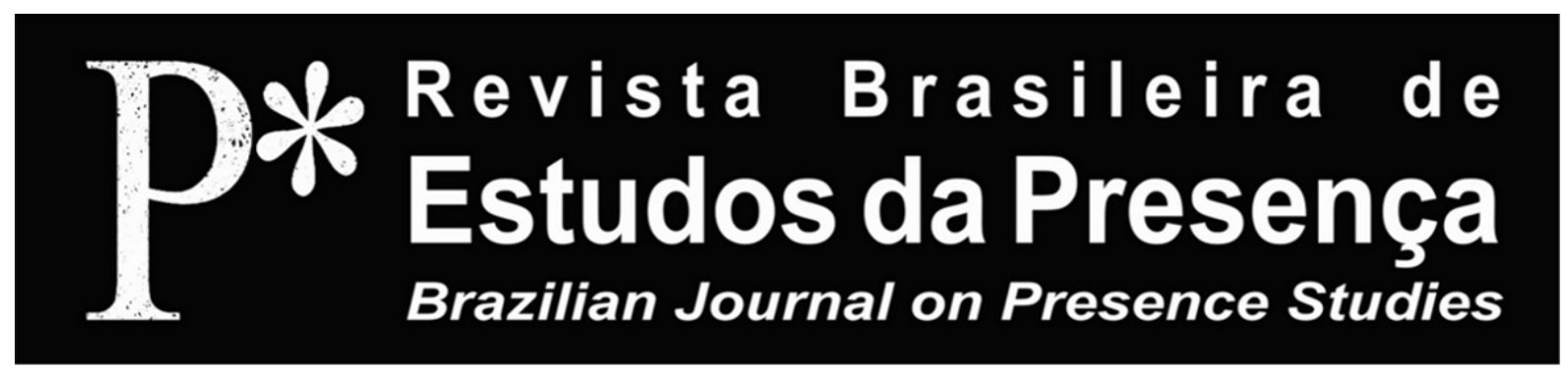

DOI - http://dx.doi.org/10.1590/2237-266041770

ISSN 2237-2660

\title{
Escaping the Representation: Lieutenantenduetten, a critical performance by the Warme Winkel
}

Esther Gouarné

Université Paris Ouest Nanterre - Paris, France

\begin{abstract}
Escaping the Representation: Lieutenantenduetten, a critical performance by the Warme Winkel ${ }^{1,2}$ - This performance questions the logics of representation and mimesis, blurs the borders between life and fiction, and mixes codes inherited from the theater, performance-art, and happening. It plays with art history to address the difficulty of art to create images in a globalized world, and more specifically, in the context of the current European economic crisis, which directly threatens the art scene in Holland.
\end{abstract}

Keywords: Dutch Collective. Site-specific. Performative Acting. Distance. Representation.

RÉSUMÉ - Sortir de la Représentation: Lieutenantenduetten, une performance critique du Warme Winkel - L'exemple évoqué dans article remet en question les logiques de la représentation et de la mimesis, brouille les frontières entre la vie et la fiction en mêlant les codes du théâtre, de l'art de la performance et du happening. La performance de Warme Winkel joue avec l'histoire de l'art pour réfléchir sur la difficulté de créer de l'art et des images dans le contexte de la crise économique qui atteint actuellement l'Europe et qui menace directement la scène artistique néerlandaise.

Mots-clés: Collectif Néerlandais. Site Spécifique. Jeu Performatique. Distance. Représentation.

RESUMO - Sair da Representação: Lieutenantenduetten, uma performance crítica do Warme Winkel - Esta performance questiona as lógicas da representaçáo e da mímesis, faz divergir as fronteiras entre a vida e a ficção, misturando os códigos do teatro, da arte da performance e do happening. A performance do Warme Winkel joga com a história da arte para refletir sobre a dificuldade da arte em criar imagens no contexto da crise econômica atual da Europa, e que ameaça diretamente a cena artística holandesa.

Palavras-chave: Grupos Holandeses. Site-specific. Atuaçáo Performativa. Distância. Representação. 
How can the performative codex of the avant-garde performanceart transform the basic principles of theater practice? Studying Dutch collectives belonging to the family of the vlakke vloer ${ }^{3}$, something struck me in many performances: the representation exhibited and revealed the creative process, situated the show in a direct continuum with the time of the rehearsal, granting it thereby a quality of immediate presence and spontaneity, close to the presence of the performer in the context of a happening.

To understand this phenomenon, we need to look back at the recent history of the Dutch theater. Numerous vlakke vloer venues ${ }^{4}$, companies, and actors' collectives developed in Holland in the 1970s and 1980s, contributing to significant changes in the methods and aesthetics on a long-term basis. Different trends emerged at that time that put the emphasis on the bodily presence of the actor, on his spontaneity, and his ability to improvise, in reaction to traditional text-based theater as it was practiced in large venues. Mime techniques played an important role in various schools and conservatories where new departments were created - for instance the mime and directing courses in the Amsterdam Theaterschool. The influence of collective and devised theatrical forms developed by the American avant-garde programmed at the Mickery ${ }^{5}$, as well as that of performance-, action-, and body-art were also crucial to a lot of young practitioners in search of non-linear, non-narrative, and not text-based forms - all of which Lehmann later termed as typically post-dramatic. In the 1980 s and 1990 s, techniques of montage and fragmentation were frequently used to deconstruct the logic of representation and create new approaches to the theatrical text ${ }^{6}$, if and when it was still used. The notion of actor-creator, or theatermaker, emerged and was placed at the heart of creative processes in actors' collectives, but also in the practice of a lot of directors, who put the emphasis on improvisation and discussion. What is left of this inheritance in the practice of young Dutch collectives? And how does theatrical performance respond aesthetically to the current crisis and to the political decisions threatening the working conditions that emerged at that period to support those new forms?

I will here focus on the example of the Warme Winkel, and more specifically on Lieutenantenduetten, which displays tools inherited from the performance-art, anchored in the creative process. Indeed, 
the acting clearly blurs borders between fiction and reality, and the play is conceived as a shared event rather than a fixed end-product. Besides, this aspect of the Warme Winkel's work is reinforced by the presence of a pioneer from the former generation, invited as eindregisseur (final director) in this project: Marien Jongewaard. He was a major figure in the development of a critical and polemical mime trend in the 1980s and 1990s. He encourages the performers of the Warme Winkel to go further in the direction of non-matrixed presence, full bodily commitment, and explicit political content.

\section{Presentation}

Lieutenantenduetten is a site-specific performance created in the Vondelpark's bunker in Amsterdam. It is freely inspired by Ernst Jünger's Lieutenant Sturm and his War notebooks. Two lieutenants are hiding in a bunker, and escape the reality of the battlefield by remembering their favorite pieces of art and literature and by playing theatrical roles: art appears as the last bastion of peace and beauty in a violent world, and the play addresses the problem of drastic budget cuts affecting the cultural sector since $2010^{8}$.

The aesthetics at stake require to consider the play as a process and as a performative event as a whole, and not as an autonomous end-product. That is precisely what theoretician Fischer-Lichte points out when she identifies what she calls the "performative turn" occurring in the arts in the 1960s.

Contingency became a central aspect of performance with the performative turn of the 1960s. The pivotal role of the audience was not only acknowledged as a pre-condition for performance, but explicitly invoked as such. The feedback loop as a self-referential, autopoietic system enabling a fundamentally open, unpredictable process emerged as the defining principle of theatrical work (Fischer-Lichte, 2008, p. 39).

That is why we chose to analyze this play in relation with its creative process. We will observe how the site-specific location and the real time/real action codes contribute to partly blur the boundaries between rehearsals and representations, and we will then be able to analyze the political implications given to these performative codes. 


\section{The Creative Process}

Working as a collective, the performers of the Warme Winkel devise their plays discussing topics and themes together, and gathering materials of all sorts as the starting point of each creation. Books, films, pictures are studied and then more or less integrated directly in the piece. The play is indeed never written nor pre-conceived at the beginning of the process; texts and forms take shape progressively. Discussion, research and reading are thus crucial in this process. The other major aspect, complementary to this one, consists in the creation of acts (act or action) that performers present daily to one another. The act combines pure presence and complex acting from the start of the project, and guarantees the embodiment of ideas and themes - whereas some collectives work mostly around the table until the very last week of the process. Constantly dealing with those two aspects of the creation and conceiving the piece while trying to act it out at the same time, the performers are authors and theatermakers in charge of the whole process, and never really abandon their critical distance towards what they are playing, thinking, and imagining altogether. That results in a peculiar way of being on stage in-between the full physical and emotional engagement on the one hand, and the critical, even ironical distance, on the other hand. The acts can be of various lengths, from about one to fifteen minutes; they can be visual, music- or text-based; they can already require a scenographic installation or technical effects, or just consist in a reading, as all styles and forms are explored by the Warme Winkel. The acts are sometimes discussed in advance and decided collectively, and sometimes they are just imagined by one member of the group, who then surprises the others with it. In this example, they can be performed by one of the two performers, sometimes by both, and sometimes, in my case, with me as an assistant in the process, trying out some of their propositions when a third performer was needed.

An act is a kind of private happening that is prepared but not rehearsed, performed only once and shown to the few people present at that time and place. The whole process can therefore be seen as a series of unique and original happenings, most of which are never reproduced afterwards. In the end, some of them are put together and transformed in the final montage to be presented to the public. A living archive of the creation is constituted during this period, 
as every act is given a title written down on a piece of paper, that is hung on the walls of the rehearsal space, so that everybody can consult and modify it.

During the montage, which occurs in the last two weeks of the process, these papers are physically manipulated and classified in order to visualize the possible structure of the play to come, when materials are sorted out and chosen. At that moment, the performers decide which elements will be shown or not to the public, in which order, and with which rhythm, style, and energy level. They are helped in this phase by the eind-regisseur ${ }^{9}$, in this case Marien Jongewaard. He points out the weaknesses from an outside point of view, and helps find the appropriate form of the final play starting from the materials assembled and created by the performers beforehand. With the intervention of this third eye, Weemhoff and Rietveld become more fully spelers (actors), putting their whole energy on the stage, as they delegate some of the composition choices to someone else.

Nevertheless, this quality of being on stage remains strongly rooted even in the moment of the representation, where the performers seem to present their proposition more than they represent it. This slight critical distance participates in an acting-style strongly rooted in the present moment, where the process seems to go on evolving in front of the audience, and where things could still, at least virtually, change. The actors are in this case manipulating theatrical symbols and codes. In other words, they are showing-acting, to use the vocabulary set up by Richard Schechner, who defines performing precisely as the action of showing-doing (Schechner, 2006, p. 22). According to this definition, the performer not only acts and realizes an action in front of the audience, but underlines the process towards this action, exposes the impulses and motives of this action, and actually presents himself as a performer executing it.

\section{The Process-Play Continuum}

Since the first research at the Black Mountain College, performance-art developed a conception of art where the accent is put on the process more than on the spectacular or plastic result; painters, musicians, and visual artists started exposing themselves while making their work of art. They stand for a philosophy where the how prevails over the formal qualities of the end product ${ }^{10}$. The 


\section{( Estudos da Presenca

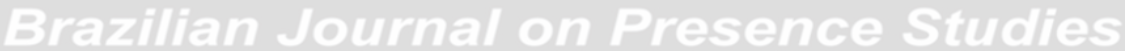

Warme Winkel integrates this principle by showing the theatermaking process, instead of absorbing it in a fictive situation or an immersive environment. A clear sign of this border-blurring between process and art-object appears on the walls of the Vondelpark bunker, where the papers of the acts are still hung and remain there during the representations. This physical trace of the rehearsal connects the different moments of the performative process as a whole: the acts, the montage, and the public representation.

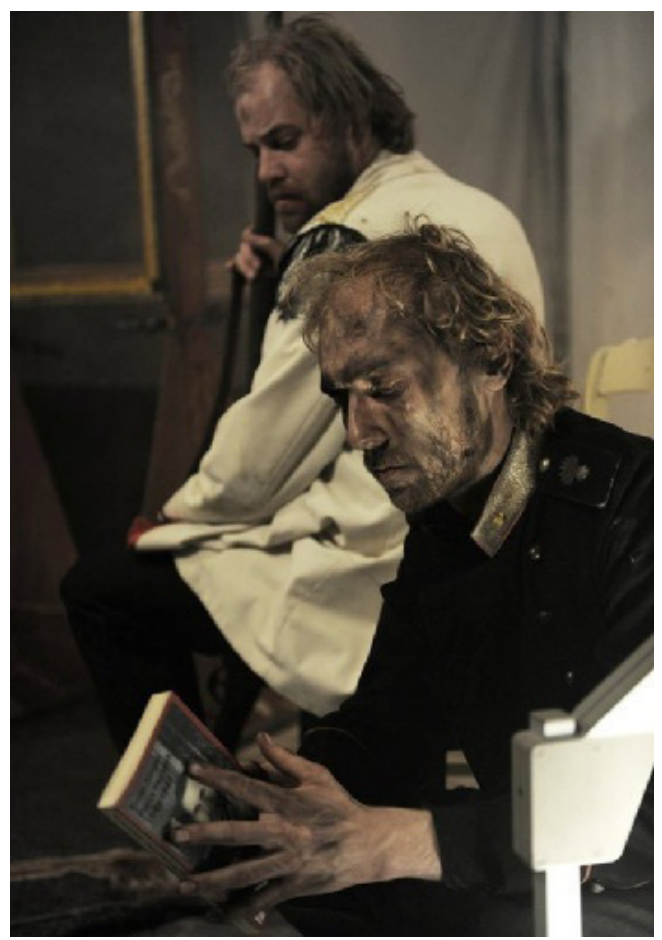

Illustration 1 - Vincent Rietveld and Ward Weemhoff. Reading a book: the research taken from the rehearsal table to the audience. De Warme Winkel, Amsterdam, April 2011. (C) Sophie Knijff

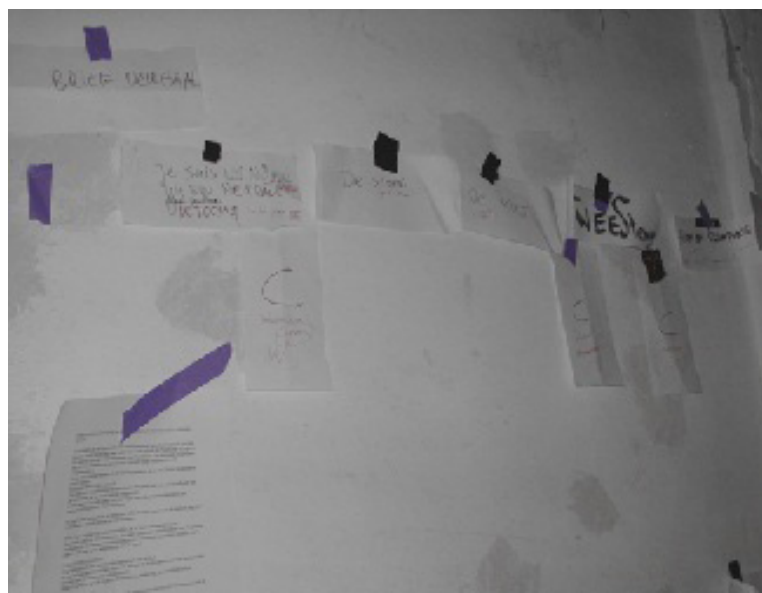

Illustration 2 - The acts on the bunker's wall. De Warme Winkel, Amsterdam, April 2011. (C) Esther Gouarné

EstherGouarné-EscapingtheRepresentation:Lieutenantenduetten, acritical performancebytheWarmeWinkel Rev. Bras. Estud. Presença, Porto Alegre, v. 4, n. 1, p. 28-46, Jan./Apr. 2014. Available at: <http://www.seer.ufrgs.br/presenca > 
Books used during the research are also brought on stage, sometimes read out loud and shown to the public. They can function as an invitation to participate in the research and to start reading ourselves. They introduce the spectator to the very sources of inspiration beyond the play itself, which are shown as specific moments in a longer literary, historical, philosophical, existential research, here related within a specific form which doesn't, or shouldn't, put an end to it. This is the first performative continuum that characterizes the theatrical performances of the Warme Winkel.

\section{The Time-Space Continuum}

The second performative continuum consists in a time-space linearity that inserts the play in its larger context. The use of the specific site helps to insert the representation itself into the broader circle of the performance, understood by Schechner as:

[...] the whole constellation of events, most of them passing unnoticed, that takes place in both performers and audience from the time the first spectator enters the field of the performance - the precinct in which the theater takes place - to the time the last spectator leaves (Schechner, 1973, p. 8).

His definition echoes the emergence of what he calls environmental theater in the 1970s, upon which he bases his analysis and his performance theor $\mathrm{y}^{11}$. Whereas they indeed pass unnoticed in most of what Schechner calls "orthodox theater" - mostly textbased, traditional and taking place in official venues, these events are explicitly displayed by the performers and the organizers in the context of site-specific and environmental performance. That can explain why site-specific theater is a significantly wide-spread phenomenon in Holland since the 1970s, influenced at first by the American groups to be seen at the Mickery, a place where relations between spectators and performers were constantly challenged and where the environment was always experienced as part of the performative event. Afterwards, experimental groups such as Hollandia (created by Johan Simons and Paul Koek) used factories, industrial, urban, and natural spaces, and a myriad of festivals ${ }^{12}$ were created all over the country, that specialized in the programming of site-specific forms. The Warme Winkel has perpetuated this tradition since the beginning, working in museums, farms, cultural centers etc. Weemhoff and Rietveld here 
use the bunker both as a historical setting and as an environment where the performance can be shared and experienced, accentuating its quality as a live and interactive event: as Erika Ficher-Lichte points out, since the 1960s: "The bodily co-presence of actors and spectators enables and constitutes performance" (Ficher-Lichte, 2005, p. 41). The aesthetics and theoretical tools she promotes to analyze this type of theater is based on this liminal experience at the heart of each performance. When they buy their tickets, the spectators do not know the exact location where the show takes place, but they are instead given an appointment in the Vondelpark, where a crew member welcomes them, and leads them all to the bunker. This procedure creates a mystery around the location, which can provoke a certain complicity among the members of the audience and gives deliberate shape to the performance environment. The boundaries between beginning and end are thus blurred: the event already begins when people book their tickets, and on the evening itself it begins in this unusual gathering under a bridge. The play is integrated in a continuum between what happens before and after it. At the end, the time-line of the performance is blurred again in the extra-theatrical life as a table is set and beers are served so that, immediately, spectators and performers can have a drink and talk together. Discussions and debates can develop about the topics raised during the show, among others, and this strengthens the virtual possibility of the public's participation in the performative research. The theatrical play is therefore not sharply cut off from the temporality of life itself, this "impure" time-space Schechner established at the left end of his performative spectrum to seize the notion of environmental performance (Schechner, 1968, p. 42); the artistic proposal is situated on the other end at the right side of it, as a "pure" time-space. But in this environmental performance, the play is indeed not radically separated from another type of performative event, such as a politically engaged discussion that could take place in an underground literary society.

The use of a specific site such as the bunker and the mise-en-scene around it helps to integrate the peripheral aspects of the performance with the proposition, and creates the appropriate setting for a global performative event rather than for a mere theatrical representation. Inside the play itself, the performative aesthetics produces distant 
and critical images that deconstruct pre-conceived representations. We will here focus on the example of war images, which illustrate the predominance of the here-and-now reality of the presentation over the reality of definitive, autonomous, and complete images.

\section{The Example of War Images}

Whereas war is clearly placed at the heart of the whole creative process, and is used both as historical and literary material, it slowly disappears in the time of the montage when the performers choose to simplify the scenes, removing all superfluous props and all exaggerated, spectacular or grotesque forms of acting. Lieutenantenduetten is more minimalistic than the previous plays of the Warme Winkel, which were generally quite baroque, and goes further in the re-appropriation of the performance codex. It is not used here as an explicit reference shown and humorously re-enacted, as it happened in former plays, but is deeply rooted in the aesthetics, and it helps the performers to stand up against the usual image processing in the media, and, in particular, the media treatment of war images.

First of all, war is here characterized by its absence in the first two thirds of the play, where the two performers are dressed in contemporary urban outfits and first establish eye contact with the audience, visibly waiting for something, exhausted and nervous. They hereby establish the code of the performance, which happens in the here and now, in real time, for the few people assembled at that particular evening in the bunker - that is about fifty spectators. They then evoke iconic figures of historical and political minorities: The Woman, The Nigger, The Artist, therefore using symbols such as the wedding dress and the black make-up (see illustration 3). 

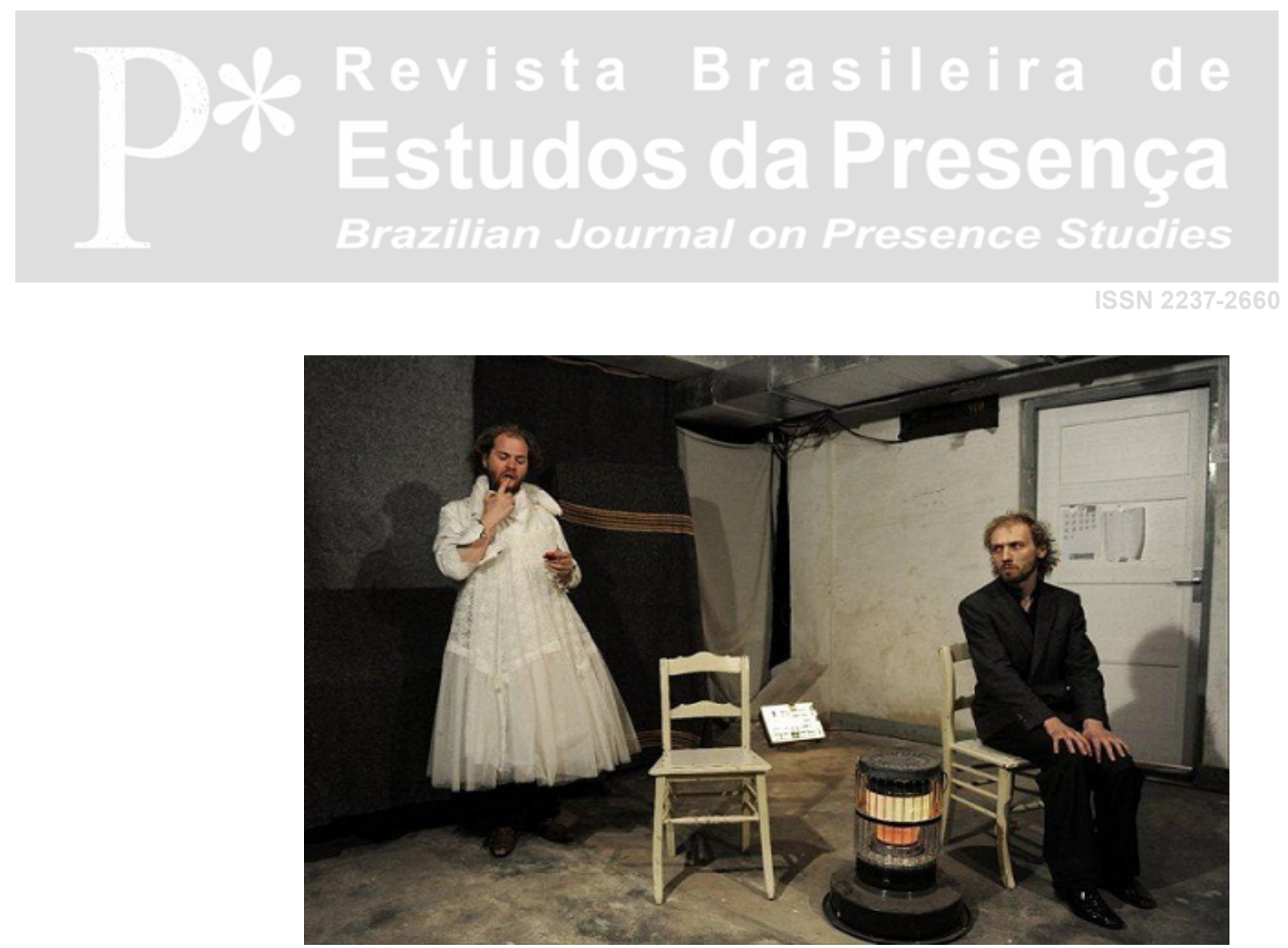

Illustration 3 - Vincent Rietveld and Ward Weemhoff. Playing with archetypes and symbols at a certain distance: showing-acting The Woman with a wedding dress and red lipstick. De Warme Winkel, April 2011, Amsterdam. (C) Sophie Knijff.

This beginning thus indicates another referential line at the background of the performance: Rietveld and Weemhoff are here to set up a metaphorical self-portrait of the contemporary artist, and use this figure as well as that of the lieutenant to evoke their own feelings about recent political and economic changes that affect their work and status. No soldier is to be seen in the beginning, which is all the more surprising as it is announced in the title itself: a duet of lieutenants. War thus appears as a metaphor to designate the political and economic decisions threatening the art sector in Holland - and in Europe. This humorous self-portrait plays with the cliché of the romantic artist, misunderstood and isolated in a violent and chaotic world which he is trying to save - by perpetuating and transmitting art forms, and to escape - by hiding underground. It is taken both seriously and ironically: the performers display a nostalgic feeling towards a past culture, but also denounce the seclusion of the artist in a small elitist circle, and address the need to open up and face the issues at stake in the world.

The performance takes place outside of war, away from the battle field, but the bombing and the explosions could interrupt it anytime. The specific site creates a surrounding that cannot but evoke it, and everything becomes very significant in such a context: walls shudder each time a tram passes by, and the performers move 


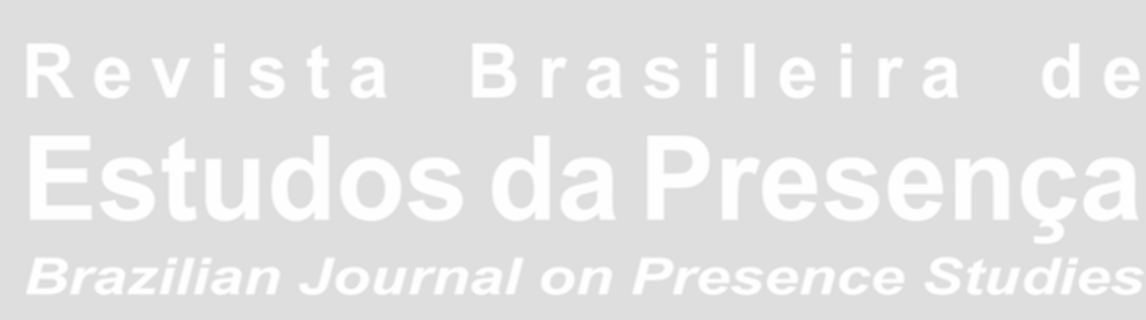

and speak extremely slowly, carefully, and low, as if they were hiding from an outside threat. Suggestion prevails thus on representation, and the performers rely fully on the real space of the bunker, with its historical roots and its peculiar atmosphere, and on the real events such as those linked to the public transportation system, instead of adding extra-layers of meaning, interpretation, and mimesis to it.

The fundamental performative code - real space/real time/ real action - takes over the theatrical representation of war in this play. Besides, the Warme Winkel thereby produces a suggestive performance focusing on the artists' attempt to represent war rather than on the production of war images, and that constantly reminds the audience of the material, as well as the practical and technical frame where this attempt takes place. That is in a time and space where war images are omnipresent via screens and papers, but where the actual epicenters are located at a safe distance, in a foreign and far-away time/space reality, miles away and/or decades ago.

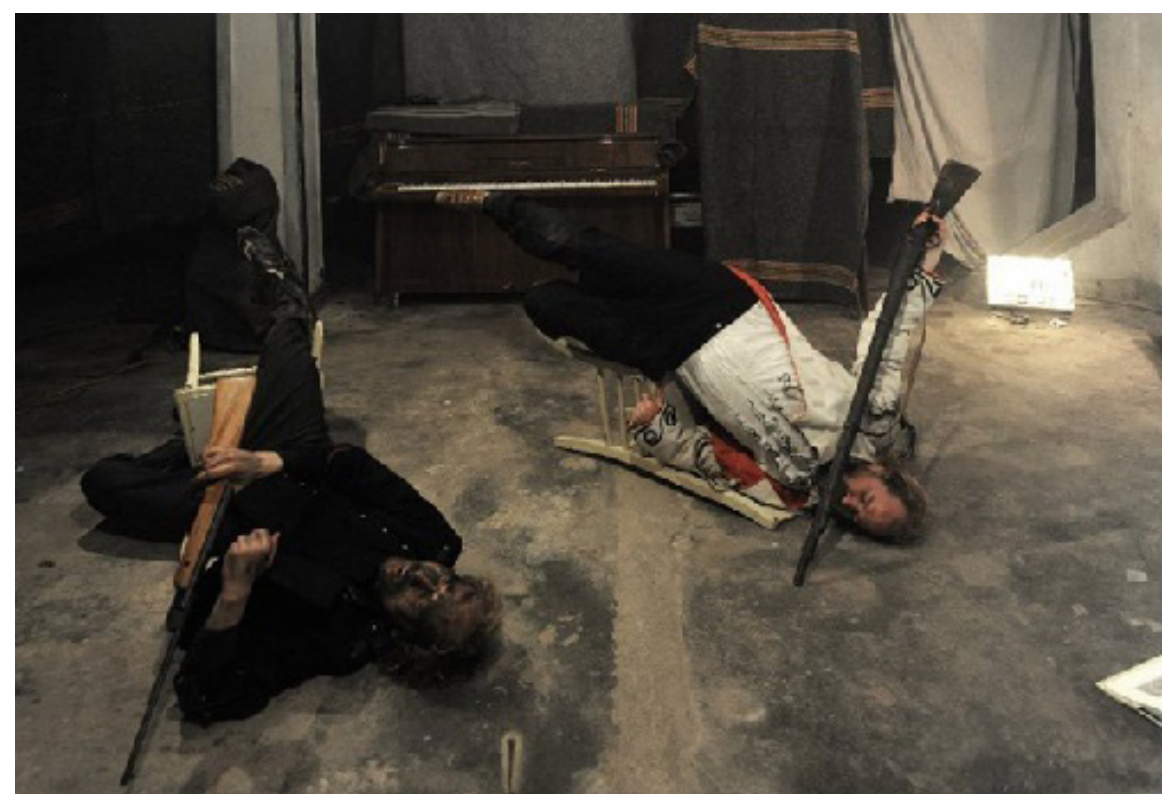

Illustration 4 - The war choreography: minimalism, humor, discrepancy. De Warme Winkel, Amsterdam, April 2011 (C) Sophie Knijff.

Then, when the two performers finally change clothes to start playing soldiers, inserting at that moment an actual representation of this unspoken and unseen reality, they both escape realistic and hypertrophied representations by executing a very abstract choreography that takes over the code of the marches. It is first accompanied by an old-fashion military band soundtrack and then 
by This is the End from the Doors, an iconic song that became intrinsically linked to cinematographic war images since the success of Coppola's Apocalypse Now. The Warme Winkel mixes references and symbols strongly rooted in the post-modern sensibility, easily recognizable but detached from their original context. This process inserts gaps, distortions, and distance in them and reflects on the mechanisms of the representation itself, without taking any image for granted. And the performers do so while always keeping their own critical self-conscience while acting, not obliterating their identity as makers who play with those representations in the performative frame of the theatrical event shared with their audience.

Whereas the media operation consists precisely in showing to the (tele)-spectators an image that is disconnected from its context, detached from the double continuum we pinned down above which characterizes the historical performance: that of the creative process and the time-space environment. Instead, war in this context becomes a suggested and implicit background that escapes representation, omnipresent but resisting its reduction in images, and all images shown are consciously exposed as imperfect and necessarily incomplete. The performance of the Warme Winkel does not directly reflect the mechanisms of the media image by integrating virtuoso digital and cinematographic techniques to its proposition - screens, videos, avatars etc. - nor by competing theatrically with their virtuosity, which is another common trend in post-modern theater. They choose instead a radically different approach by reducing the image to the scale of the performative hic-et-nunc. In so doing, they implicitly oppose the images produced by the performance to those broadcast in the media and they expose what Marie-Jozé Mondzain pins down as the fundamental lack located at the core of each "image", to which she opposes the so-called completeness of "visibilities ${ }^{13 "}$ (2003, p. 10).

\section{Exiting the Representation: towards a final happening}

Lieutenantenduetten exposes the mechanisms of devised theatermaking, and inserts the theatrical representation in the hic-et-nunc experience of a collective event, therefore standing for a type of performance that nourishes social and cultural debates. In this fragile and intimate form, the performers actually invite their audience to 
experience an event cut from daily life, where a community can gather and take time to listen to poetry, to look at bad reproductions of famous paintings, and, most of all, to experience the fact of being together. This feeling of being together is what underlines the performative hic-et-nunc and the site-specific event, and it is also accentuated when the performance is shown as a process rather than as an object.

In this example, the theatrical logic fails in its attempt to show war realities and war images, leaving them deliberately incomplete and unfinished. The final scene sets up a real get-away from the theatrical representation, completing the border's blurring between fictional, past, and present temporalities, between acting and being, between pretending and doing, between performer and spectator, and, last but not least, between art and market.

Indeed, as Rietveld and Weemhoff come to bow, they distort this convention - playing once again with theatrical rituals and codes, and transform it into an ultimate role-play while starting to ask for money. The performance being based on free participation, people do not pay when they book their tickets. In the end, they are thus driven to decide and ask themselves what is the value of art, after having participated in this experience where two performers try to save artistic chefs d'oeuvre from a massive destruction, and fight for a humanistic way of debating ideas and values.

The performative effect of this interaction is real and all the more concrete, as people actually react by talking, laughing, and of course, paying. This scene can be seen as a happening in the sense that it is each time unique and shared by individuals present at that time, and changes according to the number of spectators, their state of mind and that of the performers, and it reinserts fully the predominant strength of the here and now. It also has a performative effect, here understood in the Austinian sense ${ }^{14}$ (Austin, 1962): it transforms the reality, depriving the spectator's bank account from something that goes to the collective's, but at the same time repossessing him of his own opinion and choice. He is not considered as a passive consumer of art, but as an active participant in the cultural and social debate: this finally makes explicit the "transformative power" of the performative event that Fischer-Lichte (2005) points out, as a fundamentally interactive art form, where materiality and semioticity go hand in 
hand, and where, as Fischer-Lichte puts it: "These shifts make the traditional distinction between the aesthetics of work, production, and reception as three heuristic categories seem questionable, if not obsolete" (Fischer-Lichte, 2005, p. 19).

The whole performance, as we have shown, contributes to keep the spectator at a distance from all representations and images in order to give him the space to interpret and actively question them, to judge and analyze the process he is watching, and also larger economic, political and cultural issues at stake. The performers push this logic at its maximum extent in this final twist: "[...] artistic performance opens up the possibility for participants to experience a metamorphosis" (Fischer-Lichte, 2005, p. 23). The scene also highlights the metaphors and symbols displayed throughout the performance by re-focusing on the real situation of the two performers, Weemhoff and Rietveld, who are then speaking in their own name, as two members of a collective from the Dutch vlakke vloer, in the context of the European economic crisis and of the drastic budget cuts in the cultural sector. The value of art is here replaced at the heart of the performative proposition, as it was in the performance-art that was precisely conceived to resist market logic and escape cultural institutions. The position of the two artists is here biased, their speech oscillates between rebellion and irony, as they are themselves totally integrated in the current system, even more so as they still belong to one of the few subsidized vlakke vloer groups in 2012.

Romanticism and humanism irrigate the whole performance, but in the end they are ironically designated as obsolete mythologies. They cannot be the answer to conflicts and misunderstandings in such a globalized world. To close down in a small secluded space and to celebrate there the last fragments of a past sensibility seems anachronistic: the artists engage more explicitly and address current issues in their last happening.

The liberal-capitalistic rhetoric is distorted and diverted by this both parodic and very serious speech of self-legitimization, as the so-called romantic artists reveal their skills as marketing agents, fully aware of their own subscription to the current system: the time of idealism and utopianism is over - that is what they seem to tell us, with a mixture of cynicism and nostalgia. But by doing so, they also 
denounce the easy categorizations between victims and persecutors, innocent and guilty, and remind us that everybody takes part in the global system. Once again, the performative vocabulary contributes to the blurring of all too clear and sharp borders, between seriousness and humor, as well as between politically engaged art and marketbased phenomena.

The performance thus oscillates between two logics: idealism and cynicism, naïvety and irony, or, in other words, between modernism - , as the time of big narratives, myths, and utopic systems, and postmodernism, - as the time of fragmentation, dissolution of meaning, and irony. The performers are looking to re-connect with artistic and political ideals such as those of 19th century romantics and, closer to us, with those of the 20th century avant-gardes, as both movements put a lot of faith in the power of the artist to change the world. But at the same time, they are deeply rooted in post-modern disillusion and cynicism. This last scene questions all the representations previously displayed, that is to say the faith in humanistic values and art forms, the romantic mythologies, and the rebellious spirit of the performance-art avant-garde. Not to renounce them, but to reinsert them in the contemporary context: how could these values survive in a world where clear enemies are widely scattered all around and among us, and how to invent new ones capable of resisting the virtualization of conflicts, financial transfers, and human relations?

\section{Performance as Resistance}

The methods, vocabulary, and aesthetics of the Warme Winkel are characterized by the mingling of references inherited from different trends of art history, and especially from the performanceart. They do not re-enact the avant-garde happenings, and they do not pretend to revive the 1970s spirit, but they refer to them in an ambivalent way, between the respectful homage, the nostalgic farewell, and the humorous critic. Above all, they invent a form of performative acting that is spontaneous, physically and mentally engaging, and completely iconoclastic. I have shown how the borders between two logics, the non-matrixed presence of the performance and the highly matrixed ${ }^{15}$ role-playing of the theater, are blurred in Lieutenantenduetten. That constant blurring installs a discrepancy within every scene and figure, and characterizes a performance that 
doesn't give up on representation and image-making, but manipulates them cautiously. This paradoxical performance embodies an attitude of resistance towards the trivialization of, on the one hand, violent images and news, and, on the other hand, violent economic and political decisions, but with a post-modern distance that prevents it from displaying a unique vision on art and/or society. 


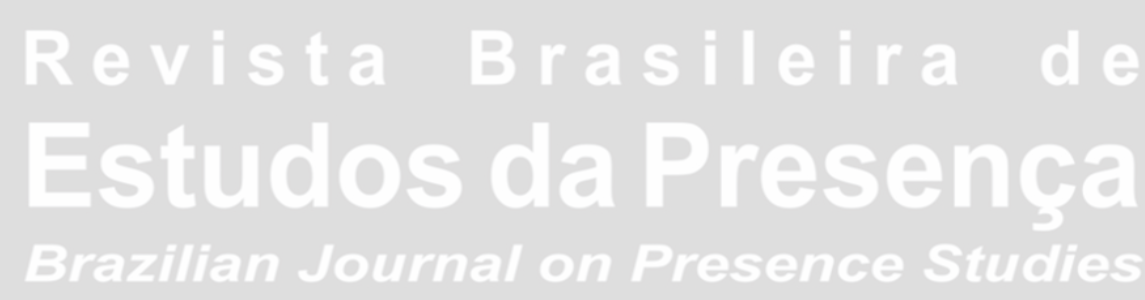

\section{Notes}

${ }^{1}$ This article results from a communication during the 2013 conference of the International Federation for Theater Research (IFTR), in the working group Processus Créatifs, directed by Josette Féral and Sophie Proust.

2 Theatregroup De Warme Winkel (The Hot Shop) is an actors' collective comprising Mara van Vlijmen, Jeroen De Man, Vincent Rietveld, and Ward Weemhoff, with Jantien Ploij as business manager. It was created in 2002 after the first three members graduated from Maastricht Academy of Drama. Weemhoff joined the group in 2010 after graduating from Antwerp Conservatorium. They specialized in site-specific and historical creations, especially in the Austrian Cycle, a series of five devised plays created between 2004 and 2009 around major artists and writers taken from the Vienese fin-de-siècle. Available at: $<$ http://www.warmewinkel.nl>.

${ }^{3}$ The Dutch vlakke vloer designates a theatrical family that comprises small and mediumsized groups, with a fixed artistic and administrative core, recognized in the cultural sector, and specialized in the small theater venues or the alternative and site-specific locations. They are working in-between the big institutions and the amateurs. This trend has been developed since the 1970s, and is also linked to the expansion of actors' and artists' collectives. Maatschapij Discordia, created by Jan Joris Lamers and Mathias de Koning, is one of the most important pioneer of this trend still in activity today, and was the initiator of a new way of devised theater-making in the 1980s, where the actor is considered a direct intermediate between the text and the spectators.

${ }^{4}$ Such as Felix Meritis, Frascati, and de Brakke Grond in Amsterdam, Toneelschuur in Arnhem, Kikker in Utrecht, that played an important role in the producing and programming of young groups.

5 The Mickery was created in 1965 by Ritsaert ten Cate in an old farm in Lonersloot. It quickly acquired an international reputation and introduced a lot of American experimental groups in Europe during its annual festival - for instance La MaMa, Living Theater, Bread and Puppet, Wooster Group, and a host of others. It is subsidized since 1969 and relocated to the center of Amsterdam in 1972, contributing to the development of new forms of devised and site-specific theater, working on the blurring of borders between genres, styles, disciplines, and cultures.

${ }^{6}$ See, for example, the work of Gerardjan Rijnders, actor, writer, and director who developed his montage techniques while directing the Toneelgroep Amsterdam, and acquired thereby a national and international reputation.

${ }^{7}$ Jongewaard is the director of Nieuw West, founded in 1980 with writer Rob de Graaf and actor Dik Boutkan after graduating from the mime department in Amsterdam. It is a collective with punk and anarchist influences that invented a very performative, provocative, and politically engaged theater: <http://www.nieuwwest.nl>.

${ }^{8}$ In September 2010 a budget cut of $25 \%$ is announced in the cultural sector, promoted by the center-right coalition. As a result, in the FPK. distribution of 2012, more than half 
of the required subventions were turned down and numerous groups, festivals and venues had to close, stop or reduce their activities - among which Discordia, 't Barre Land, O.T., who were important pioneers in the 1980s.

${ }^{9}$ Literally to be understood as a final or end-director, the eind-regisseur is a common figure in a lot of collective and devised work in Belgium and Holland, since the 1970s. His/her exact function and degree of implication varies from one project to another. He/she can be a member of the group or a guest invited by the performers.

${ }^{10}$ For a synthetic approach on this subject, see Goldberg (2001).

${ }^{11}$ He was still working with the Performance Group he had created in 1967 with Liz Le Compte, which was a place of major experimentations in that field.

${ }^{12}$ Among which Oerol, Over Het Ij, Caravane, in Holland, and Theater aan Zee in Belgium are the biggest.

13 She uses this word to tackle the flow of saturated filmic, photographic, and digital pictures that tend to erase the gaps that lack in our relation to the visible by pretending to seize it and account it fully.

${ }^{14}$ Austin's theory on performativity consists in recognizing the active power of uttered words, able to transform reality as they are being pronounced. I here use the idea of performativity to express the impact the artistic speech or action can actually have on the non-artistic reality around it.

15 Term used such as defined and situated on Michael Kirby's acting-scale.

\section{References}

AUSTIN, John Langshaw. How to do Things with Words. Cambridge: Harvard University Press, 1962.

DOLAN, Jill. Utopia in Performance. Ann Arbor: University of Michigan Press, 2005. FICHER-LICHTE, Erika. The Transformative Power of Performance. London: Routledge, 2004.

GOLDBERG, Rose-Lee. Performance Art, from futurism to the present. London: Thames \& Hudson, 2001.

KIRBY, Michael. A Formalist Theatre. Philadelphia: University of Pensylvannia Press, 1987.

KIRBY, Michael. Happenings. New York: Dutton, 1965.

KRANS, Anja. Vertraagd Effect. Amsterdam: TIN, 2005.

LEHMANN, Hans-Thies. Le Théâtre Post-dramatique. Paris: L'Arche, 2004.

MONDZAIN, Marie-José. Le Commerce des Regards. Paris: Le Seuil Editions, 2003.

NIEUW WEST. Available at: <http://www.nieuwest.nl>. Accessed on: 10 oct. 2013. 
ISSN 2237-2660

SCHECHNER, Richard. Performance Studies, an introduction. New York and London: Routledge, 2006.

SCHECHNER, Richard. Six axioms. The Drama Review. New York, v. 12, n. 3, p. 4164, spring 1968.

SCHECHNER, Richard. Drama, Script, Theatre, and Performance. The Drama Review, New York, v. 17, n. 3, p. 5-36, sep. 1973.

WARME WINKEL. Available at: <http://www.warmewinkel.nl>. Accessed on: 10 oct. 2013.

Esther Gouarné is both a performer and a theoretician, currently finishing a PhD on creative processes in Dutch and Flemish collectives, based on her active participation in a few representative projects. She is advised by Pr. Christian Biet (Paris X) and Pr. Karel Vanhaesebrouck (Vrije Universiteit Brussels).

E-mail: esther.gouarne@gmail.com

This unpublished text, reviewed by Ananyr Porto Fajardo, is also published in Portuguese in this issue.

Received in August, 9, 2013 Accepted in October, 13, 2013 